\title{
THE ECONOMIC BASES OF PATENT REFORM
}

\section{Victor Abramson*}

Over the past quarter-century, the need for patent reform has had the attention of every session of Congress, and has been the subject of nearly a dozen special investigations by congressional committees and in the executive branch of the government. Within the past ten years alone, the President has on three separate occasions directed a review of patent practices and the submission of proposals for reform, twice through the creation of special committees for that purpose. Public interest in the patent question has grown with the anti-trust disclosures of the late Thirties, and with wartime evidence of the influence of patents on industries vital in the national defense.

The kind of patent reform which we should have remains, nonetheless, a bitterly controversial issue. On the one side, evidence of patent abuse has provoked suggestions for removing entirely the powers of exclusion now conferred under patents, and for denying to patent owners virtually all of the authority which they now have to impose conditions on their licensees and on the distributors and users of their products. On the other side, there have been exaggerated counterclaims of the harm which might be done through any tampering with the rights now conferred on patentees. Neither group looks with much favor on the use which the courts have made of antitrust concepts to limit the exercise of patent power. A fresh appraisal of the role of patents in the modern economy may suggest a common ground on which to reconcile these opposing views.

\section{I}

Today's patent problem is a result chiefly of the fact that little has been done to adapt the patent system to the revolutionary economic changes which have taken place since it was founded. Patents had their beginning in the age which preceded the age of invention. They came into prominence as part of the mercantile system of sixteenth- and seventeenth-century England. At that time, capital was scarce, enterprise was lethargic, and commerce was fraught with great risks both physical and financial. Many branches of industry and trade were under monopolistic con-

- A.B. 1928, West Virginia University; A.M. I931, Ph.D. 1936, Brown University. Research Fellow in Economics, Brookings Institution, 1932-33. Member of the Staff, Brookings Institution, 1933-40. Assistant Chief Economist, Consumer Division, National Defense Advisory Commission, I940-41. Economic Adviser, Rubber Division, Office of Price Administration, I94I-42. Economic Adviser, Office of Alien Property Custodian, 1942-46. Economic Adviser, Patent Survey Committee, U. S. Department of Commerce, 1946-47. Co-author (with Leverett S. Lyon) of The Economics of Open Price Systems (1936); (with Leverett S. Lyon and M. W. Watkins) Government AND Economic Life (2 vols., 1939, 1940); author of articles in various professional journals. 
trol by the towns and gilds. The purpose of the mercantile system was to provide special inducements and regulations designed to expand the commerce of England and to strengthen its industry. It served also as one of the instruments through which the national government asserted its general authority over the economic life of the nation. Patents occupied a varied role in the economy of that period, and only one of those functions has survived.

Least important, when viewed from the perspective of today, was the use of patents to bolster the revenue of the Crown and to reward its favorites. Their other principal economic functions at that time were two. Through letters-patent, the Crown granted powers of monopoly in order to encourage the undertaking of risky ventures, sometimes in foreign lands. It was thought that this inducement would bring out additional capital, and would provide both a basis of protection against marauders and an instrument through which the Crown could exercise regulatory powers. In closer correspondence to their-modern function, patents were also employed as a means of obtaining technology and skilled workmen from abroad, and to reward inventors.

Industry was then in the handicraft stage, advances in the arts were infrequent, and the communication of ideas was slow. The principal source of "new inventions" was knowledge of the crafts practiced in other lands which were more advanced than England. In order to encourage the immigration of the craftsmen who had this knowledge, the Crown granted to them the safeguard of patents. These sometimes conveyed only the protection of the Crown in practicing their crafts within the jurisdictions of the towns or gilds. The only public obligation regularly imposed on patentees was to teach their skills to others. This was sufficient to meet the needs of the time, since in order to discharge this obligation the patentee ordinarily had to set up shop for the practice of his craft. Patents were also sometimes granted to tradesmen who were the first to import a new article, in keeping with the purpose of enlarging commerce, or to those who merely established a new manufacture.

The ensuing struggle between Parliament and the Crown eventually brought forth, in 1623, the enactment of the Statute of Monopolies. ${ }^{1}$ Under this statute, all monopolies issued by the Crown were declared to be "utterly void." However, patents for the "making of any manner of new manufactures" were exempted from this stricture. The term "new manufactures" continued for some time to be interpreted to cover technology new only in England, and "first importation" or the first establishment of a new industry, as well as "new inventions" in the sense in which that term is now used.

With the advent of the age of invention, when machine and chemical technology came to supplant many crafts, written disclosures were substituted for the teaching requirement. It thus became possible for patent owners to control the use of tech-

II JAC. I, C. 3 (I623). 
nology without practicing their inventions. This was to prove of importance when the enlarged supply of capital later brought a great increase in the number of new inventions.

At the time when our own present patent system was founded, we were also greatly in need of skilled craftsmen, technology, and capital to support industrial development, and the principal sources of these were external. There was support for the view that patents should be used broadly to attract all of these essentials. But other counsel prevailed, and the first patent Act of $\mathrm{I} \mathrm{go}^{2}$ provided that patents should be granted only to those who had "invented or discovered any useful art, manufacture, engine, machine, or device . . not before known or used." A year later, in his celebrated Report on Manufactures, ${ }^{3}$ Alexander Hamilton proposed the use of tariffs and bounties to accomplish certain of the other purposes for which patents had earlier been used in England.

II

A century and a half has passed since our patent system was founded. In that time, patents have taken on a new importance in our economy, and have given rise to unforeseen problems. Yet the patent statutes remain, in every respect except administrative procedure, virtually unchanged.

During the greater part of the nineteenth century, new inventions were rare, and the chief obstacle to their commercial use was lack of capital. Only a negligible part of the economic life of the nation was influenced by the practices of patentees. Since that time, the growth of capital has greatly altered this situation. It has made research ventures, yielding benefits only in the future, and uncertain ones at that, increasingly worthwhile; and it has provided the means of using commercially the results of many of those ventures. The outcome has been a spectacular rise in the number of patented inventions. Today, a vastly greater proportion of superior technology is under the control of patentees.

This fact alone is of some public importance, since access to superior technology represents the key to entry into an industry or trade. The chance to invest in or to organize a business, to get a job, or to purchase an article or service, now depends more than ever on enterprise and rivalry among patentees who enjoy legally sanctioned limited monopolies. Forces have been at work, moreover, to diminish even this rivalry, and to extend to other fields the powers conferred under patents.

Where there is general access to industrial technology, competition can be depended upon to bring about the prompt commercial use of superior new inventions. The issuance of a patent for a new invention may diminish this prospect. The mere fact than an invention is monopolistically controlled reduces the pressure to make immediate use of it. This pressure can be maintained only if the technology open to rival firms is closely competitive. Even where the external com-

${ }^{2}$ An Act to Promote the Progress of Useful Arts, April 10, I790, I STat. Iog.

${ }^{3} 3$ Works of Alexander HaMilton 192-284 (Ed. by John C. Hamilton, I850). 
petition is strong, a patentee who owns two competing inventions, but who has already invested in production under the inferior one, may for a time find it unprofitable to use the superior one. The degree of patent concentration is thus an important factor determining the commerical exploitation of new inventions.

The tendencies toward concentration of patent ownership have been strong in the modern economy. Inventive effort is subject to greater uncertainty than exists in most other fields of enterprise. Neither the chance of a successful result, nor the probable commercial value of any discovery, can be forecast. For this reason, the larger research ventures are more likely, relative to the investment made, to turn up a successful result; and the growth of capital has made it possible to take advantage of these benefits of large-scale research. Concentration of patent control has also been favored by the advantages which lie in large-scale exploitation of many inventions, a fact to which modern technology has contributed. Thus, even where inventions are independently developed, they are often placed in the hands of firms with established production and marketing facilities in the same general field. Perhaps the most important cause of patent concentration, however, is the usefulness of patents as a device for excluding rival firms from the market.

The acquisition of patents is often sought as a means of assuring competitive survival. Since an investment already made in production and marketing facilities may be blocked from effective use because a competitor has patent control of superior technology or of a favored product, the acquisition of competing inventions' may represent the only means of safeguarding this investment. Conversely, these acquisitions are also sometimes motivated by the desire to exclude competitors from using the inventions. This practice has grown up because it represents one of the most effective, yet in some degree lawful, means of attaining market control.

To some extent, this purpose has been achieved through the research activities of individual firms. But since this is a game at which two can play, other practices have been developed with the same end in view. Where the rival firms in an industry have each been able to acquire patent control of important technology, they have sometimes agreed to an exchange of patent rights which would place each of them in exclusive control of some limited product field or market territory. The plan frequently followed has been for the participants in the exchange to agree on a division of fields or territories, and for each of them to grant to the others an exclusive license, or assignment of patent rights, pertaining to the field or territory assigned to them. Each of the patentees thus gives up partial control of technology in a broader range of fields or territories, in exchange for more complete control in a narrower range. The effect is to diminish competition in each of the fields or territories; and where the patents involved cover the only competitively effective technology, the result is to eliminate competition entirely. These effects are sometimes prolonged by an agreement to exchange future inventions according to the same pattern.

Less restrictive in their effects are the exchanges of nonexclusive licenses, some- 
times accomplished through the "pooling" of patents. The proximate effect of these exchanges may indeed be to enliven competition among the participants, in as much as they make available to each of them the inventions of the entire group. However, such arrangements sometimes provide for output and price control covering the operations of the participants even under their own inventions. Where this occurs, preexisting rivalry is likely to be restrained. And in any case, the appearance of outside competition may be obstructed. Pooling and non-exclusive cross-licensing arrangements inevitably strengthen the competitive position of the participants as against others. Some of these arrangements, moreover, forbid or limit patent exchanges with non-participants, thus perhaps blocking their access to essential patent rights.

A distinctive problem has arisen in the case of foreign-controlled American patents. Patents, even today, perform a unique function in promoting the disclosure of foreign inventions which might otherwise remain unknown to us. This function is less important for inventions developed here, because those inventions are more likely to be used to domestic advantage even though they are not disclosed. However, patents granted to foreign inventors are more likely to be used to bar production here; or, alternatively, to restrain our international commerce.

Foreign inventors sometimes acquire American patents partly for the purpose of safeguarding their domestic markets against American competition. Where this is true, they may be reluctant to issue licenses for production here unless they can control exports. And they may neglect, or find it unprofitable or impossible, to sell or-manufacture here under their inventions. Export or exchange controls at home or tariff barriers here may block either capital imports or imports of the patented article; there may be insufficient access to technology here; or it may be unprofitable to develop partial product lines. Moreover, where inventions are foreign-controlled, political or military considerations are more likely to intrude to govern their use here. This danger has become more acute with the rise of governments which intimately control the economic activity of their nationals.

These considerations have often been reflected in patent exchanges involving the nationals of different countries. In such exchanges, there have been found territorial divisions confining the participants to their home markets and certain adjacent areas, and explicit provisions prohibiting exports from those territories. Their effect is to block international commerce, and to establish exclusive control of the individual markets. In territories outside the home markets of the participants, unified control is sometimes achieved by requiring that sales be made through a common agency. Where international arrangements provide for a division of product fields, there are likely to be even more restrictive effects on supply, particularly in time of political upheaval or war. Experience has shown that such divisions of product fields have in some instances related to articles vital in the national defense or to the public welfare.

A final factor which has contributed to the non-use of patented inventions is a 
result of the division, rather than the concentration, of patent ownership. With the growth of capital, industrial research has become widely diffused; and much of it, under the inspiration of the published specifications of patent grants, has been directed toward improving or "inventing around" existing patented inventions. Partly as a result of this fact, there has arisen an enormous group of dependent inventions divided in ownership from those which are controlling.

These dependent inventions fall into two general groups. One consists of the improvement inventions which are legally blocked from use by a dominant patent, and the process inventions which are similarly obstructed by a controlling product patent, or less frequently the reverse. The other consists of inventions which, while legally and technically capable of independent use, must be employed in combination with others if the highest technical efficiency or economic value is to be achieved; or indeed, in some instances, if they are to be of any commercial worth. Where the ownership of dependent and controlling inventions is divided, involuntary non-use of the former may result, or there may be less efficient use of each of them. Non-use of a dependent invention is most likely to occur where the owner of the controlling patent is able to operate profitably without access to it.

The roles of basic and improvement patents are reversed once the basic patent has expired. The owner of the improvement patent may then be able to prevent others from making effective commercial use of the basic invention. This fact has given rise to two practices which have excited public criticism. The owners of basic patents have sometimes attempted to perfect improvements on these inventions, and to space the patenting of these improvements in such fashion as greatly to prolong their effective control of the market. In other cases, business firms have attempted to "fence in" competitors by acquiring control of improvement patents relating to the technology used by the competitors. In the first situation, broad use of the basic invention may be delayed for some time after the patent issued for it has expired. In the second, the use of improved technology is deliberately obstructed. Patentees are often aided in carrying out such plans by the fact that the owners of improvement inventions, being unable to make independent use of them, may have no choice but to sell them to the owner of the dominant patent or to some competitor of the dominant patentee who may find it profitable to purchase them as a means of restricting rivalry.

A second major criticism of the patent system has been the charge that patents are used to restrain manufacture and commerce in fields beyond the grants. The practices objected to are also of modern origin. They rest upon the fact that access to patented technology or to patented products has become highly important in many industries and trades. This has, in some instances, enabled patentees to secure from their competitors, or from the distributors of their products or those who use them, concessions which would be beyond the power of vendors of common articles of commerce.

Most common are the restrictions imposed on the licensee's use of the patented 
invention. The issuance of a license creates a new competitor for a patentee who is manufacturing under his invention. In order to safeguard his investment against this competition, the patentee may limit his licensee's output, sales, or prices. Royalty charges are often inadequate for this purpose, since these charges are limited by the terms under which competing technology is available, while the issuance of a license places the patentee's entire investment in jeopardy.

If the limitations imposed on licensees were strictly confined to manufacture and sale under the licensed invention there would be no adverse effect on preexisting competition. But this is not always the case. Often the licensee combines the licensed invention in use with others of his own, or with others which are available to all. The restrictions embodied in his license contract then affect his other operations. Moreover, patent licenses sometimes require the licensee to purchase from the licensor materials or services available from other sources, or limit the licensee's manufacture, use, or sale of other articles competitive with those manufactured or sold by the licensor. Similar provisions have appeared in patentees' contracts with their distributors and with their vendees. Even where the patentee does not manufacture under his invention, he may impose limitations on his licensees, as a means of preventing "market-spoilage," or in order to carry out a plan of price discrimination designed to enchance monopoly revenue under the patent.

These restrictions have been found in many forms in patent license contracts, and in agreements relating to the sale or use of patented products. They all rest on the fact that the invention controlled by a patent cannot be perfectly duplicated from any other source, and they all reflect an effort by patentees to take advantage of this fact to secure other business or to limit other competition.

This summary of modern patent practices, and of their economic effects, is not complete. It will serve, however, as a background for consideration of the problems of patent reform.

\section{III}

Any effort to work out a patent policy suited to present industrial conditions must take into account certain factors which make the "production" of inventions unique, and which call for distinctive measures of public policy. While patents no longer serve the purposes which they served in the day of hand craftsmanship, they are needed, for other reasons, to foster inventions based on research.

The thought that monopoly power may be required to call forth production is repugnant to the view that has generally guided our public economic policies. Our chief reliance has been on individual initiative, safeguarded by personal freedom to choose an occupation and to retain the product of work undertaken. Among the essential parts of this plan have been our efforts to facilitate entry into industry and to limit monopoly. It is unlikely, however, that these incentives and safeguards would assure a sufficient supply of new industrial technology.

Unlike most other products and services, inventions are fugitive, and their 
value cannot be recovered through the mere right of possession. Inventions consist merely of ideas, and once these ideas are known they may readily be possessed by everyone. Since it is often difficult to use an invention commercially without disclosing it, competitors of the inventor may thus be able to gain access to it without sharing in its costs. If this occurs, competitive use of the invention will tend to drive the price of the invented article to the point where the inventor is unable to gain a return for his discovery.

Several possible results would follow. There would be no incentive to invent except where it was anticipated that the invention could be commercially used in secrecy, or could be kept secret long enough to recover its costs. And wherever inventions did appear, the issuance of licenses would be discouraged since the invention could not safely be disclosed for the purpose of negotiation. Duplication of inventive effort would be more common than at present in the fields in which the incentive to invent remained. And the inspiration to further inventive effort gained through the disclosure of inventions would be largely lost.

It is often pointed out that inventions are sometimes the result of accident, or are otherwise created with little thought of the money income they would bring; but it is unlikely that the social requirements for new inventions can be met from these sources. It will be socially desirable to foster the creation of all inventions, the costs of which can be recovered through their commercial use. There may be others as well which are socially worthwhile, but these represent the minimum. Only if the social contributions which may be achieved through inventive effort are rewarded equally with comparable achievements in other fields of enterprise can there be assurance that productive resources will be used to equal social advantage in all of them. This aim cannot be accomplished so long as the commercial value of inventions may be dissipated through their disclosure in use. For today an important, if not the most important, source of new inventions is research requiring extensive capital outlays and deliberately founded upon and guided by purely pecuniary considerations.

The chief tasks of patent policy are to preserve incentives to supply inventions which meet social needs, while confining the rewards to inventors within the limits necessary for this purpose, and to the forms least likely to obstruct the commercial exploitation of the inventions or to serve as a basis for restraints in other fields of enterprise.

\section{IV}

Our present patent system represents an effort to foster inventions by offering to the first inventor the right to exclude all others from the use of his invention, and by allowing him to exercise this authority to control entry into the affected industries and trades. It has been anticipated that grants in this form would not only provide a sufficient reward to inventors, but would encourage the more rapid perfection of inventions in order to gain priority. The contrast with the public 
policies followed in other fields of enterprise is apparent. Subsequent inventors are deprived of the right to use the products of their own labor, and the freedom of entry into industrial and commercial pursuits is impaired.

Some form of private right of exclusion appears to be unavoidable unless there is to be public subsidization of research. The validity of subsequent claims would be extremely difficult to determine once an invention was disclosed, but such determinations would be necessary if the present principle of priority were to be abandoned. Further, if the number of allowed claims were great, it is likely, for the reasons indicated earlier, that the commerical value of the invention would be destroyed. It is possible that an agreement could be reached among the various inventors, but uncertainty concerning the probable terms of such an .agreement would act as a serious deterrent at the inventive stage.

It is inevitable, moreover, that any granted power of exclusion should affect entry into the industries or trades making use of, or vending, the invention. Inventions have no independent commerical value. What value they have is a derived one, resting upon the worth of the articles or services to which they contribute. For this reason, authority to control the use of an invention necessarily involves power over manufacture and commerce. The real question is how complete this power need be in order to insure a proper flow of new inventions.

Three factors are at present counted upon to limit and regulate the monopoly conferred under patents: ( $\mathrm{I}$ ) The patent grant is of limited duration; and since there is a requirement of full disclosure, free use of the invention, destroying the monopoly, presumably supervenes at the expiration of the grant; (2) based on the information set forth in the published specifications, others are free to invent and use commercially acceptable, although not technically equivalent, substitutes; (3) under interpretations of the antitrust statutes, certain patent practices are forbidden. In addition, under the standards of "invention" applied in sifting patent applications, the grants themselves are narrowly confined.

In appraising the sufficiency of these safeguards, the tests which should be applied are: (I) Do they permit the issuance of patents where monopoly power is unnecessary to assure the supply of inventions? (2) Where some form of special protection to inventions is necessary, does the authority now conveyed to patentees exceed that which is required?

While detailed examination of the standards applied in granting patents cannot be undertaken here, it appears that in economic terms they are generally satisfactory. Patents may now be granted only where the advance over the prior art exceeds that apparent to skilled craftsmen. Such advances can ordinarily be achieved only through the application of effort and the investment of capital. The use of these resources in inventive activity cannot be counted upon unless the earning capacity of the results is protected against dissipation through disclosure of the invention. Without some form of such protection, the public would be deprived of many valuable inventions which could be made commercially worthwhile under proper 
safeguards. It is not feasible to single out the individual cases in which nonpecuniary factors motivate inventions.

The principle of limiting the patentee's return to that which can be gained commercially in competition with other technology prevents the deliberate use of the patent system to foster inventions which may have no social value, although it does not, of course, forestall such inventions. This is not to say that there may not be inventions which are worth promoting on some other basis. But there appears to be little relationship under our patent system between the risks assumed in inventive effort and the returns which may be gained under patents.

Limited duration of the patent grant, when applied on a uniform basis, is an insensitive device for this purpose. Inventions vary greatly in the state of their technical perfection for practical use, in the time required to initiate their commercial exploitation, and in the period necessary to amortize their costs even under the most diligent promotion. The period now in force has no meaning in an age in which new inventions are largely the product of research, and relate chiefly to technology which requires the extensive use of capital. Originally, we adopted the fourteen-year period then followed in England. This had been based on the time required for a craftsman to train two new sets of apprentices. The seventeen-year grant, now in effect, is the result of a compromise reached when an effort was made to extend the time to twenty years in lieu of the seven-year renewal then allowed. It would be hopeless, however, to attempt an individual proportioning of the grants in accordance with the time required to recoup the costs of the invention.

Reliance on the freedom to invent and use substitutes offers a more promising approach, if bolstered by certain safeguards not now provided. Patentees are required to disclose in "full working terms" the nature of their inventions. These "specifications" are published after the patent is issued and are made generally available at a nominal charge. Further, the protection granted under a patent covers only the technical equivalents of the invention, and not necessarily those which may compete with it in a market sense. Thus, far from providing effective protection against commercial rivalry, our patent system encourages the invention of commercially acceptable substitutes in so far as this is consistent with powers of exclusion relating to individual inventions.

The freedom to invent substitute techniques and products is not likely to work as effectively as freedom of entry does in the lines of enterprise in which it is fully preserved. The results of inventive activity are too uncertain, and it is unlikely that perfect substitutes will always be found. Moreover, in the case of product inventions even minor differentiation, particularly when supported by a patent, is likely to afford some degree of monopoly control of the market. Yet it is probable that further measures designed to maintain the competition among patented inventions are the best means of safeguarding the public interest.

Some excess of returns over costs in the case of unusually successful inventions may perhaps be justified, even though it could not be in forms of enterprise in which 
there is fairly accurate advance knowledge of cost and market conditions. The unusual risks which characterize inventive effort may attract those who prefer a gamble over a sure thing, even though the prospect of loss may greatly exceed the prospect of gain. But these conditions are likely to discourage other prospective inventors. The attraction offered by potentially great profits may thus be indispensable if a proper flow of inventions is to be insured. How far this is true cannot be determined; and there is the danger that excessive returns in unusual cases will over-stimulate inventive effort and lead to wastage of productive resources.

\section{$\mathrm{V}$}

The third factor now relied upon to curb unjustifiable gains through the use of the patent monopoly calls for separate consideration, since it represents one of the chief subjects of proposed patent reform. This is the use of antitrust concepts to limit the exercise of patent power. The patent statutes themselves do not restrict the use of the patent monopoly, nor do they provide any standards by which limitations might be imposed. And, except for one section of the Clayton Act, ${ }^{4}$ no statute provides explicit criteria by which to judge in clear terms propriety in the use of patents.

Over the years, a body of law relating to the industrial and commercial use of patents has been built up through judicial decisions. In passing upon the patent practices which have come before them for appraisal, the courts have appeared to follow two lines of policy not always clearly distinguished. They have found certain practices to be beyond the "four corners" of the patent monopoly. And where a practice has been so held, it has been judged by criteria laid down in the antitrust statutes. In the absence of clear statutory guidance, the evolution of these judicial policies has been marked chiefly by indecision. Practices sanctioned at one time, and subsequently widely followed in business relationships, often have later been overturned, and today the field of patent law abounds in uncertainty.

Many of the difficulties which have been encountered in the development of judicial policy in this field may be traced to the inherent unsuitability of the antitrust statutes as an instrument for the control of publicly sanctioned monopolies. They are at once insufficiently lenient and insufficiently strict for this purpose. Yet they suggest the lines along which a proper patent policy may be developed.

The licensees of a manufacturing patentee are inevitably his competitors. However, the wisdom of allowing patentees to control the competition which appears from this source cannot be judged solely by antitrust standards. Without some authority to limit output and sales under a licensed invention, it is probable that patentees would issue fewer licenses. This might result in less efficient production and less active exploitation of markets. The allowable forms of limitation on the use of licensed inventions can rarely be found by reference to the antitrust statutes, since there can be no earlier or potential competition against which to measure

38 STAT. 73 I (I9I4), I5 U. S. C. $\$ I_{4}$ (1940). 
their effects. The strict application of these statutes would, in fact, require a complete ban on agreed restrictions, a policy which the courts have never followed. It would seem preferable to frame legislation designed specifically to regulate private use of the patent monopoly. Through such legislation, restrictions over licensees in the forms most necessary to encourage broader licensing could be sanctioned, and those least necessary for that purpose, and those most likely to have an adverse effect on competition in other fields, could be explicitly banned.

In contrast, anti-monopoly provisions which may effectively safeguard the public in fields which are free of patents are likely to prove inadequate for dealing with the concentration of patent control. The centralized ownership of competing inventions is likely to have a more harmful influence on the competition in an industry than a comparable concentration of other assets. The physical plant and distributive facilities of business firms are, in some considerable degree, reproducible, so that a transfer of these assets to a rival firm does not necessarily remove the threat of competition. The grant of exclusive rights under patented technology, however, will completely bar the grantor from the industry unless he is able to gain access to what is certain to be the limited supply of competing technology. If the concentration of patent control proceeds far enough it may result in the lawful exclusion of all rivals, subject, of course, to the limitations now imposed by law. The public has a further interest in limiting the concentration of patent ownership, since this is the most effective means, short of compulsory licensing, for insuring use of the most efficient technology, for holding the returns to inventors within proper limits, and for restraining the use of patents to limit competition in other fields of enterprise. For these reasons, concentration of patent ownership must be resisted more jealously than other forms of industrial concentration.

The same is true of a wide variety of agreements which limit competition. A limitation which might have no substantial effect on competition without the use of patents as a sanction might loom to considerably greater importance where it could be enforced through the deprivation of patent rights. Moreover, as was pointed out earlier, patentees áre likely to be more successful in gaining such concessions from competitors. Restrictive agreements involving the transfer of patent rights may thus have to be limited more carefully than others.

\section{VI}

The remedy which has had the greatest appeal to many advocates of patent reform is the general compulsory licensing of patented inventions. This approach has, above all, the attraction of apparent simplicity, and there seems to be a precedent for it in the controls which have been imposed upon the public utilities.

If it could be successfully administered, the public benefits which might be derived from the general compulsory licensing of patented inventions would indeed be many. Inventions would be unlikely to lie idle because of inertia, and even less so because of design. The owners of dependent inventions would have ready access 
to essential auxiliary technology. Since all could use the most advanced technology, production generally would be on a higher level and prices would reflect this fact. Even without disturbing the returns to inventors, output and price policies could become competitive. And the influence of the patent monopoly could more readily be confined within the bounds of the grant.

The administrative difficulties of general compulsory licensing, however, are formidable if not overwhelming. Inventions are not homogeneous products. Neither the cost nor the value of a new invention can be determined on the basis of past experience with other inventions. Moreover, because new inventions are unique, it is likely to take some time before their worth can be demonstrated. In setting royalty rates, it would be necessary to take into account the probable useful life of the invention, considering prospective advances in technology, and to estimate the probable returns at alternative royalty rates. Further, the rates set for competing inventions would have to be carefully proportioned to their relative worth. And, somehow, consideration would have to be given to the costs of creating the inventions. To make these determinations for some forty thousand or more patents a year would be virtually impossible, and the price of poor administration might be an adverse effect on the flow of new inventions. It has been suggested that the rates now "typical" could be followed. But it is difficult to classify new inventions according to old categories; the rates now charged in fact vary greatly within categories classified on a technical basis; and, if general compulsory licensing were inaugurated, there would cease to be an independent source for rate determination.

Intimate public regulation of rates and conditions of service has been undertaken in the public utility industries. But the conditions which brought forth such regulation in those industries do not prevail generally in the industries which employ patented inventions. In fact, a comparison of the two groups of industries, in so far as they can be distinguished, suggests an important difference and points to a principle which should properly guide patent reform.

Rates and conditions of service are regulated in the case of the public utilities chiefly because competition in those industries is considered to be both unenforceable and socially wasteful. The principle of confining intimate regulation to situations in which these conditions prevail has been observed, by and large, in our public economic policies, except in times of acute scarcity. Adherence to this principle is, it may be said, vital to the preservation of a private enterprise system.

In both patents and public utility charters there are public grants of private monopoly. But public utility charters, unlike patents, are granted partly for the purpose of facilitating public regulation. The unusual cost conditions which prevail in the public utility industries have motivated the difference in treatment. The minimum investment required to attain the highest level of technical efficiency in those industries is so great, relative to the size of the market for their services, that production is ordinarily carried on at a point at which the provision of additional service costs less than the average cost of the total services provided. Where this 
is true, profitable operations require that prices be maintained above "marginal cost," and it may also be necessary to discriminate in prices in order to cover full costs of production. This can be done only if there are limitations on competition. An attempt to maintain competition under these conditions could lead only to unnecessary commitments of capital and ruinous price-cutting, or, alternatively, to retarded development of the industry. Failure to maintain competition, on the other hand, would lead "naturally" to monopoly or to agreement, express or implied, among the competitors. Monopoly has therefore been sanctioned in those industries, and entry limited on the basis of "public convenience and necessity," as a means of encouraging their development, of preventing over-building, and of facilitating public regulation of conditions of price and service.

No such considerations have motivated the grant of patent monopolies, nor are the powers conferred under patents comparable to those granted under public utility charters. The objective of the patent grant is to foster invention. Whatever power there may be over the exploitation of inventions is incidental to this purpose. Not only is protection against competing inventions withheld, except as to technical equivalents, but their creation is deliberately encouraged through the disclosure requirement and the maintenance of free entry into inventing. And, in contrast with public utility charters, the patent grant is limited in duration without relation to the continued commercial use of the-invention.

The view persists that patents are designed, and are necessary, to assure the commercial use of new inventions. Patents could bring more prompt commercial development of inventions, and in some few cases might be indispensable to such development, since they improve the prospect of high profits and diminish the risk of loss through competition. But without enforced use, such as through compulsory licensing, they could have the opposite effect. Moreover, considered broadly as a matter of public policy, it cannot be said that the commercial development of new inventions stands in greater need of special encouragement than other fields of enterprise, or offers any greater prospect of public benefit. Many patents, in fact, are for improved means of manufacturing known products, or for improved forms of such products, and so are not subject to unusual risks in exploitation. There is less to be said, socially, for holding out special inducements to overcome uncertainties of demand than to overcome risks which are the result of cost conditions. The conclusion cannot be escaped that the idea of using patents to divert production in favor of the chosen subjects of the grants is a vestige of an era in which enterprise lagged and in which the government played a larger role in choosing lines of industrial and commercial endeavor.

The arguments here suggested against the general compulsory licensing of patented inventions do not necessarily hold against the more restricted application of this remedy in cases of patent abuse or to overcome protracted idleness of patented inventions. If compulsory licensing were so confined its administration would be 
greatly simplified, and it has a special merit for dealing with certain types of patent practice which may be considered to run counter to the public purposes of the patent grant.

VII

The foregoing discussion does not present any specific plan of patent reform. The purpose has been to set forth certain economic considerations which should be taken into account in appraising any program which is presented. The challenge of patent reform is to avoid, on the one hand, the burdening of government with tasks which could be accomplished through the maintenance of more effective competition in the use of patented inventions, and, on the other hand, to avoid too heavy reliance for the regulation of these limited monopolies on the safeguards now provided under the patent and antitrust statutes. This is a challenge rarely met in the proposals now most frequently advanced. 